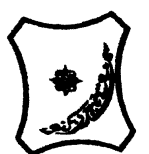

Bayero Journal of Pure and Applied Sciences, 9(2); 70 - 75

Received: June, 2016

Accepted: October, 2016

ISSN $2006-6996$

\title{
PARTIAL PURIFICATION AND CHARACTERIZATION OF ANGIOTENSIN CONVERTING ENZYME INHIBITORY PEPTIDE FROM SCARLET RUNNER BEANS (PHASEOLUS COCCINEUS) SEEDS
}

\author{
Abdulazeez, A.M. ${ }^{1}$, Osumeje, G. $^{2}$ and Kurfi, B.G. ${ }^{3}$ \\ ${ }^{1}$ Center for Biotechnology Research, Bayero University, Kano State, Nigeria. \\ ${ }^{2}$ Department of Biochemistry, Ahmadu Bello University, Zaria, Kaduna State, Nigeria \\ ${ }^{3}$ Department of Biochemistry, Bayero University, Kano State, Nigeria. \\ Corresponding Author, Abdulazeez A.M +2348034509063
}

\begin{abstract}
In the present study, an angiotensin converting enzyme (ACE) inhibitory peptide from fresh seedpods of scarlet runner beans (Phaseolus coccineus) was partially-purified via a two-step process: acetone precipitation and gel filtration chromatography. The ACE inhibitory activities of all fractions were determined by a spectrophotometric method. The amino acid composition, effect of temperature, $\mathrm{pH}$, digestive enzymes and metal ions on the activity of the partially-purified peptide were determined. From the results, the crude proteins from seedpods of Phaseolus coccineus had a specific inhibitoryactivity ofo.046 $\pm 0.002 \mu \mathrm{mol} / \mathrm{min} / \mathrm{mg}$, which increased to $0.064 \pm 0.004 \mu \mathrm{mol} / \mathrm{min} / \mathrm{mg}$ after acetone precipitation. Gel filtration chromatography with sephadex G-50 further increased the specific inhibitory activity to $0.169 \pm 0.021 \mu \mathrm{mol} / \mathrm{min} / \mathrm{mg}$ at a purification fold of 3.40 and yield of $12.8 \%$. The peptide contained seventeen amino acids with Glutamic acid at $13.63 \mathrm{~g} / 100 \mathrm{~g}$ protein being highest. The optimum $\mathrm{pH}$ and temperature of the peptide was 7.0 and $40^{\circ} \mathrm{C}$, respectively. The activity of the ACE inhibitory peptide was strongly inhibited by $\mathrm{Na}^{+}, \mathrm{Mg}^{2+}, \mathrm{K}^{+}$, and $\mathrm{Ca}^{2+}$ but enhanced by EDTA. Pepsin and trypsin also significantly $(p<0.05)$ decreased the activity of the partially-purified peptide.In conclusion, this study has shown that angiotensin-converting enzyme inhibitory peptide can be isolated from Phaseolus coccineus, but the purification steps needs to be modified to obtain a peptide with higher yield. Keywords: Phaceolus coccineus, Angiotensin converting enzyme, peptide,
\end{abstract}

\section{INTRODUCTION}

Hypertension is a common and often progressive disorder that poses a major risk for cardiovascular diseases, diabetes, stroke and renal disorders. Recent data have revealed that the global burden of hypertension is growing at an alarming ratewith an estimated $25 \%$ increase in the next ten years (Mittal and Singh, 2010). It is well documented that hypertension could have many causes, and a prominent factor among allis over-activation of the renin angiotensin aldosterone system (RAAS) (Schmieder et al., 2007; Persson et al., 2009). Angiotensinconverting enzyme (ACE) plays a key role inRAAS by producing angiotensin II, which is a potent vasoconstrictor (Ottaviani et al., 2006). Therefore, in thepast decade, inhibition of ACE has become a key therapeutic target in the treatment ofhypertension. Common ACE inhibitors currently in use include captopril, rampiril, lisinopril, enalapril etc. all of which have undesirableside effects (Schmiederet al., 2007). As a result an increased interest in finding non-toxic and effective ACE inhibitors from natural food source is on the increase.These alternatives include medicinal plantsknown to be of great importance to the health ofindividuals and communities, many of which areused as spices and food plants. In recent years ACE inhibitory peptides have been isolated from hydrolysates of many food materials (Chia-Linget al., 2012; Abdulazeez et al., 2015).

Phaseolus coccineus also known as Scarlet Runner beans originated from Mexico around 900 AD (Freytag and Debouck, 2002), is now cultivated all round the world. It belongs to the family 'Leguminoseae' and genus, 'Phaseolus' and occupies the third position in the economic ranking among the different Phaseolus species (Westphal, 1974). The stem, leaves andseedpods are nutritious and widely consumedas food, while the bark and the roots are used in folk remedies.It is an unconventional legume that contains nutritionally useful quantities of most of the essential amino acids and adequate amounts of the limiting amino acids and also a good source of essential minerals (Aremu et al., 2006). Scarlet runner bean is known for its high starch and protein content, which can be carboxymethylated into products with economic, health and medicinal purpose. In the pharmaceutical industry, carboxymethylated starch (CMS) is used as disintegrant in tablets and it has also been reported that CMS is preferably used as osmotic agents for adjusting the toxicity of drugs especially medicinal solutions for parenteral administration based on the swelling and solubility properties, and hence, its use in the treatment of dialysis (Sutie, 1969; Akinterinwa et al., 2014). 
BAJOPAS Volume 9 Number 2 December, 2016

In vivo and in vitro studies indicate that the fresh seedpods, seeds and stem extracts of $P$. coccineus possess anti-inflammatory, antibacterial, anti-fungal and anti-hypertensive properties. They also promote wound healing (Figen, 2006). P. coccineus contains the peptide coccinin, in the seed and stem of scarlet runner beans, which has a strong antifungal activity. Previous phytochemical studies on $P$. coccineus have reported the presence of carotenoids, flavonoids, thiamin, niacin, glucosinate, glycosides, isothiocynates saponins, free anthraquinones, alkaloids, flavonoids and phenolics (Mizutaniet al., 1984), however, literature on its ACE inhibitory activity is scarce. The present study is aimed at partially-purifying an ACE inhibitory peptide from the fresh seedpods of scarlet runner bean (Phaseolus coccineus) characterize, and determine its inhibition pattern.

\section{MATERIALS AND METHODS}

\section{Chemicals and reagents}

Hippury-histidine-leucine (HHL.), ACE from rabbit lung, Silica gel, Sodium Chloride, Sodium Diphosphate, Sodium Monophosphate, Sodium Hydroxide, Hydrochloric Acid, Biuret Reagent, Bovine Serum Albumin, Acetone, Ethyl Acetate, Potassium Diphosphate, Potassium Monophosphate(Sigma Chemical Co.,St Louis, MO, USA). All other reagents and chemicals used were of analytical grade.

Plant material

Fresh pods of Phaceoluscoccineus were obtained from Sabon-Gari market, Zaria, Kaduna State Nigeria, and authenticated by a botanist at the herbarium of the Department of Biological Science, Ahmadu Bello University Zaria, Kaduna State, Nigeria.

Partial-purification of ACE-inhibitory proteins fromPhaseoluscoccineus

The fresh pods were washed under running water, macerated with phosphate buffer at $\mathrm{pH} 7.4$ at a ratio of $1: 10$. The mixture was then centrifuged at $4^{\circ} \mathrm{C}$ and $10000 \times \mathrm{g}$ for 15 minute to obtain the supernatant, which was bottled and stored in a cold room until when required.

\section{Cold acetone precipitation}

The supernatant was precipitated using cold acetone at a ratio of $1: 4$. The tube containing the precipitated protein was vortexed and incubated at $-20^{\circ} \mathrm{C}$ for one hour after which it was centrifuged for 10 minutes at $4^{\circ} \mathrm{C}$ and $10000 \times \mathrm{g}$. The supernatant was discarded leaving the pellet. Acetone was allowed to evaporate from the uncapped test-tube. The pellet was reconstituted in $5 \mathrm{ml}$ phosphate buffer $(\mathrm{pH} 7.4)$ to determine the ACE-inhibitory activity and protein content.

\section{Gel filtration using sephadex G-50}

The reconstituted protein was subjected to gel filtration chromatography with sephadex G-50. The gel was soaked overnight in phosphate buffer $(\mathrm{pH}$ 7.4). The column was packed with the gel and washed with the same buffer. The protein was then poured into the column and allowed to elute at a flow rate of $0.5 \mathrm{ml} / \mathrm{min}$. Thirty(30) fractions of the sample was collected, $5 \mathrm{mls}$ each. The protein content and ACE-inhibitory activity of each fraction was determined and fractions with the highest ACEinhibitory activity pooled together.

\section{Protein estimation}

Protein content of the fractions was determined according to Biuret method using serum bovine albumin (BSA) as the standard and the concentration was expressed in milligram per millilitre.

\section{Determination of ACE-Inhibitory Activity}

The inhibitory activity of ACE was determined as described by Cushman and Cheung (1971). Briefly, the inhibitor solution (protein-rich fraction) was added to a test-tube containing 5mMhippuryl-histidineleucine $(\mathrm{HHL})$ previously dissolved in $0.1 \mathrm{M}$ potassium phosphate buffer containing $0.3 \mathrm{M} \mathrm{NaCl}(\mathrm{pH} 8.3)$. Then the enzyme, ACE was added to the mixture and incubated at $37^{\circ} \mathrm{C}$ for 30 minutes. The reaction was terminated by adding $0.25 \mathrm{ml}$ of $1 \mathrm{M} \mathrm{HCl}$, and $1.5 \mathrm{ml}$ ethyl acetate was added to extract the hippuric acid formed by the action of ACE. The ethyl acetate was removed by heat evaporation, and residual hippuric acid ( $\mathrm{HA})$ dissolved in $3 \mathrm{ml}$ of deionized water. The absorbance of the solution was taken at $300 \mathrm{~nm}$ to determine the hippuric acid concentration.

Inhibition was expressed as the concentration of inhibitor that inhibits $50 \%$ of ACE-activity $\left(\mathrm{IC}_{50}\right)$, and was calculated using a non-linear regression from a plot of activity versus inhibitory concentration of at least five separate determinations. Each assay was performed in triplicate. One (1) unit was expressed as the potency showing $50 \%$ ACE-inhibition under these conditions, which corresponds to $1 \mu \mathrm{mol}$ of hippuric acid, released by hydrolysis of $\mathrm{HHL}$ per minute per millilitre of inhibitor.

Determination of Inhibitory Pattern and Measurement of Kinetic Constants

To investigate the ACE inhibitory pattern of the partially-purified peptide, various concentrations of the substrate $(0,1,2,3,4$, and $5 \mathrm{mM})$ were treated in the assay system. The ACE activity was determined both in the presence and absence of 0.5 and $1 \mathrm{mg} / \mathrm{ml}$ of the partially-purifiedpeptide at $37^{\circ} \mathrm{C}$. The Michaelis Menten constant, $K_{\mathrm{m}}$ the inhibition constant, $K_{\mathrm{i},}$ and the $V_{\max }$ were obtained from the Lineweaver-Burk plots.

Characterization of the Partially Purified Peptide from Seedpods of $P$. coccineus

Effect of pH and Temperature on ACE Inhibitory peptide

The effect of $\mathrm{pH}$ on the ACE-inhibitor was determined by varying the $\mathrm{pH}$ of reaction mixture from 3 to 10 , while the influence of temperature on inhibitory activity was analyzed by varying the incubation temperature from 10 to $70^{\circ} \mathrm{C}$.

Effect of some metal ions on the ACE inhibitory peptide

ACE activity was determined in the presence of the monovalent and divalent metal ions of Chloride, Sodium, Potassium, Magnesium and Calcium as well as EDTA.

Effect of some digestive enzymes on the ACE inhibitory peptide

Theeffect of trypsin and pepsin on the activity of the ACE inhibitory peptidewas determined as described by Choi et al. (2001). 
Briefly, digestive enzymes (pepsin and trypsin) were added to the partially purified ACE inhibitor. The reaction mixture was incubated at $37^{\circ} \mathrm{C}$ for one hour and the reaction stopped by standing in boiling water bath for 10 mins.After centrifugation at $2800 \mathrm{xg}$, the supernatant was assayed for ACE inhibitory activity.

\section{Determination of Amino Acid Profile}

The Amino Acid profile of the partially purified peptide was determined using methods described by Benitez (1989). The known sample was dried to constant weight, defatted, hydrolyzed, evaporated in a rotary evaporator and loaded into the Technicon sequential Multi-Sample Amino Acid Analyzer (TSM).

\section{RESULTS}

\section{Partial purification of ACE inhibitory peptides}

The steps involved in the purification of Angiotensin converting enzyme inhibitor are summarized in table 1 below. The crude enzyme inhibitor had a specific activity of $0.046 \pm 0.002 \mu \mathrm{mol} / \mathrm{min} / \mathrm{mg}$ at $100 \%$ yield. The precipitated proteins after undergoing purification 1.3 times emerged with a percentage purity of 48.4 $\%$ and a specific activity of $0.064 \pm 0.004 \mu \mathrm{mol} / \mathrm{min} / \mathrm{mg}$. On further purification, the specific activity increased to 0.169 $\pm 0.021 \mu \mathrm{mol} / \mathrm{min} / / \mathrm{mg}$ with a percentage yield of $12.8 \%$ and purification fold of 3.40 .

From the gel filtration chromatography elution profile, there was a gradual decrease and increase in ACE activity with no specific rhythm, with an increase in percentage up to fraction 6 . Fractions 23 and 26 were pooled together as they had the highest inhibitory activity and protein content (figure 1).

Table 1:Purification table of the partially purified ACE inhibitory peptide from seedpods of P.coccineus

\begin{tabular}{llllll}
\hline Purification Step & $\begin{array}{l}\text { Protein } \\
\text { Content } \\
(\mathrm{mg} / \mathrm{ml}\end{array}$ & $\begin{array}{l}\text { Inhibitory } \\
\text { Activity } \\
(\mu \mathrm{mol} / \mathrm{min})\end{array}$ & $\begin{array}{l}\text { Specific Inhibitory } \\
\text { Activity } \\
(\mu \mathrm{mol} / \mathrm{min} / \mathrm{mg})\end{array}$ & $\begin{array}{l}\text { Purification } \\
\text { Fold }\end{array}$ & $\begin{array}{l}\text { Yield } \\
(\%)\end{array}$ \\
\hline Crude & 11.40 & 0.556 & 0.046 & 1 & 100 \\
$\begin{array}{l}\text { Acetone } \\
\text { Precipitation }\end{array}$ & 4.02 & 0.269 & 0.064 & 1.30 & 48.4 \\
Gel Filtration & 0.40 & 0.071 & 0.169 & 3.40 & 12.8 \\
\hline
\end{tabular}

$1 \mathrm{U}$ of inhibitory activity was defined as the amount of the inhibitor that decreased the ACE activity by $50 \%$

Effect of pH and Temperature on the partiallypurified ACE inhibitory peptide

The highest ACE inhibitory activity of the partiallypurified protein was obtained at $\mathrm{pH} 7.0$ and temperature of $40^{\circ}$ Cand then subsequent decrease. The activity of the peptide inhibitor increased as the temperature increased from $20^{\circ} \mathrm{C}$ through to $40^{\circ} \mathrm{C}$ and then decreasedwhen temperature was further increased.
Effect of Gastrointestinal enzymes on the partially-purified ACE inhibitory peptide

Treatment of the partially-purified ACE inhibitor with pepsin and trypsin, significantly $(P<0.05)$ decreased its inhibitory activity compared to the control (0.071 \pm $0.17 \mathrm{mg} / \mathrm{ml}$ ). The ACE inhibitory effect of captopril $(0.127 \pm 0.14 \mathrm{mg} / \mathrm{ml})$ was significantly $(P<0.05)$ lower than the control $(0.071 \pm 0.17 \mathrm{mg} / \mathrm{ml})$ and peptides treated with pepsin $(0.305 \pm 0.024 \mathrm{mg} / \mathrm{ml})$ and trypsin $(0.242 \pm 0.015 \mathrm{mg} / \mathrm{ml}$ ) (Figure 1).

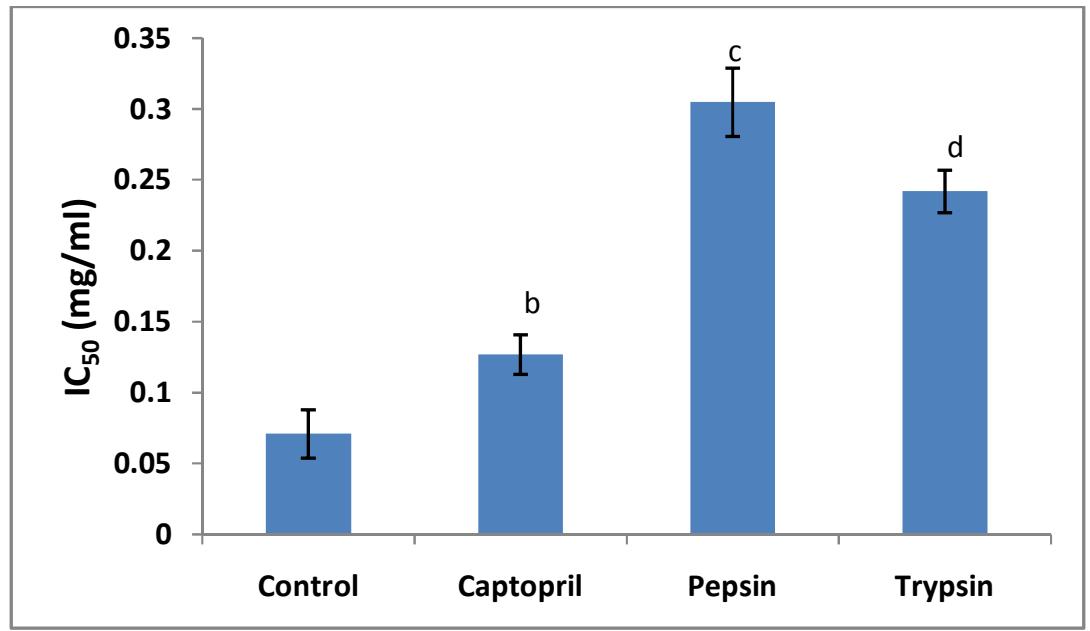

Figure 1: Effect of some gastrointestinal enzymes on the ACE inhibitory activity of partially purified peptide from $P$. coccineus

$a, b$, Mean values having different superscript letters are significantly different $(P<0.05)$

$\mathrm{IC}_{50}$ defined as the concentration that inhibits $50 \%$ of the angiotensin converting enzyme activity 
Effect of some metal ions on the partiallypurified ACE inhibitory peptide

Figure 2 below shows that $\mathrm{Na}^{+}, \mathrm{Mg}^{2+}, \mathrm{K}^{+}$, and $\mathrm{Ca}^{2+}$ decreased the activity of the partially-purified peptide, while EDTA enhanced it. This shows that the partially purified protein may be a good metal chelator. This is consistent with the result obtained by Dorrer et al. (1970).

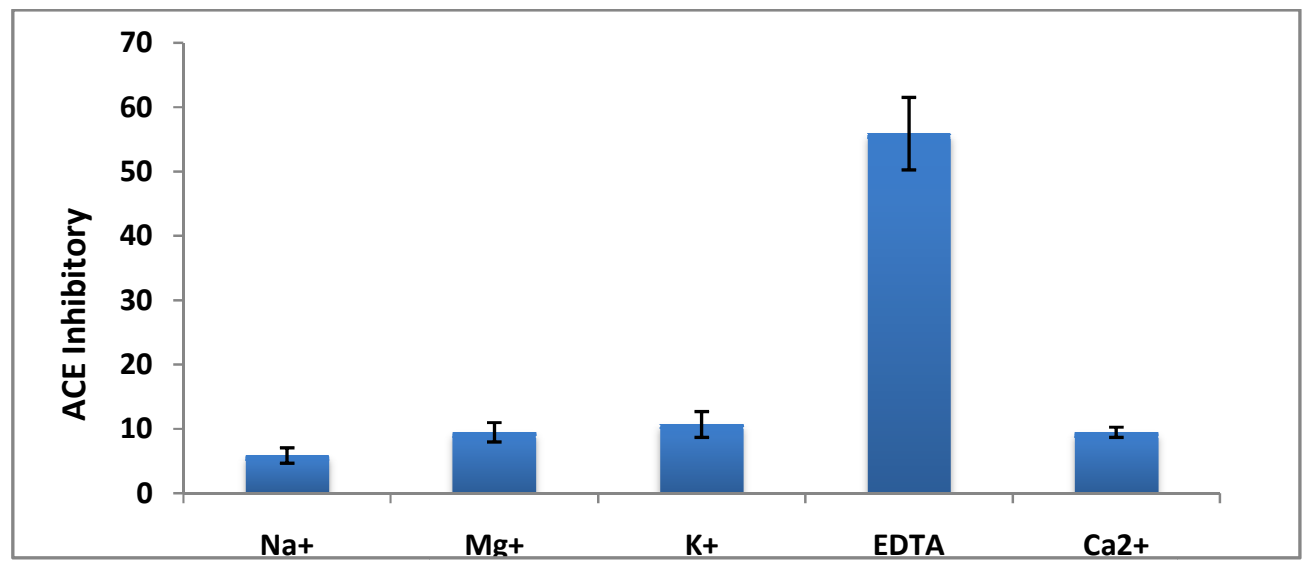

Figure 2: Effect of some metal ions on the ACE inhibitory activity of partially purified peptide from $P$. coccineus

Amino Acid Analysis of the Partially purified ACE Inhibitory Peptide

As shown on table 2, the partially-purified ACE inhibitory peptide from $P$. coccineuscontained seventeen (17) amino acids havingGlutamic acid $(13.63 \mathrm{~g} / 100 \mathrm{~g}$ protein) at the highest concentration, and Cysteine $(0.79 \mathrm{~g} / 100 \mathrm{~g}$ protein) the least.

Table 2: Amino acids present in the partially purified ACE inhibitory peptide from $P$. coccineus

\begin{tabular}{ll}
\hline Amino Acids & Concentration (g/100gprotein) \\
\hline Lysine & 6.51 \\
Histidine & 2.52 \\
Arginine & 5.01 \\
Aspartic acid & 9.00 \\
Threonine & 3.86 \\
Serine & 3.69 \\
Glutamic acid & 13.48 \\
Proline & 4.17 \\
Glycine & 5.96 \\
Alanine & 5.24 \\
Cystine & 0.79 \\
Valine & 4.20 \\
Methionine & 2.08 \\
Isoleucine & 3.20 \\
Leucine & 6.55 \\
Tyrosine & 2.86 \\
Phenylalanine & 3.88 \\
\hline
\end{tabular}

\section{DISCUSSION}

Hypertension is recognized as major risk factor for the development of many chronic diseases (Kearney et al., 2005)and since RAS plays a significant role in the pathogenesis of hypertension, ACE inhibitors have long been known for their beneficial effects in reducing high blood pressure (Brown and Hall, 2005). ACE inhibitors reduce blood pressure by preventing the conversion of angiotensin I to angiotensin II, a potent vasoconstrictor. They also degrade bradykinin, either by binding to the active site as a substrate for the enzyme or as a non-substrate, hence, inhibiting the activity of this enzyme ultimately results to low blood pressure (Viernes et al., 2012). Green tea, blueberry, Hibiscus sabdariffa and Senecioina equidens extracts were reported to inhibit ACE with
IC $_{50}$ values of $125 \mu \mathrm{g} / \mathrm{ml}, 46 \mu \mathrm{g} / \mathrm{ml}, 91 \mu \mathrm{g} / \mathrm{ml}$ and $192 \mu \mathrm{g} / \mathrm{ml}$, respectively. Although hypotensive properties of some plant bioactive constituents have been widely reported (Loizzo et al., 2007; Ojeda et al., 2010), very little has been done to determine such properties in $P$. cocineus.

In the present study, using the spectrophotometric method of Angiotensin converting enzyme inhibitory activity by Cushman and Cheung (1971), an angiotensin converting enzyme inhibitory peptide was partially purified from Phaseolus coccineus (Scarlet runner bean). The ACE inhibitory activity of the partially-purified inhibitor was lower when compared to that of Hibiscus rosasinensis $(0.43 \pm 0.04 \mathrm{U} / \mathrm{ml})$ and Vinica leaves $(1.37 \pm 0.06 \mathrm{U} / \mathrm{ml})$ (Aprilita et al., 2013). 
This might be as a result of differences in assay condition, source of $\mathrm{ACE}$, plant source and substrate used.

Phaseolus coccineushas some medicinal uses, which have long been recognized in the Ayurvedic and Unani systems of medicine (Gupta et al., 2012), but there is little or no information on the ACE inhibitory effects of its bioactive constituents. This study shows that inhibitory peptides are found in fresh pods of $P$. coccineus and inhibit ACE in vitro. It is well established that in vitro analysis offers the best opportunity and insight to widen analysis in different directions.

The partially-purified peptide showed maximum ACE inhibitory activity at the $\mathrm{pH} 7$ and the temperature of $40^{\circ} \mathrm{C}$. This result conforms to reports by Bernstein et al.(2013) that the optimum $\mathrm{pH}$ and temperature of most ACE peptidesfalls within a pH range of 7 to 8 and temperature range of 37 to $40^{\circ} \mathrm{C}$.

The effect of gastrointestinal enzymes on ACE inhibitory peptides is important because after ingestion, their activities may either increase or decrease as the enzymes may break up peptides. Though it is often expected that the peptidesare able to resist gastrointestinal hydrolysis after oral intake, this is not always the case. This may be attributed to variations in the type of ACE-inhibitory peptides liberated after treating with different enzymes (Barbana and Boye, 2011). Studies have shown that a decrease in ACE inhibitory activity of a peptide after treatment with gastrointestinal enzymes does not make it ineffective, as they may still maintain their

\section{REFERENCES}

Abdulazeez, M.M., Ndubuisi, T.C., Mohammed, I., Abdullahi, S.A., Chintem, W. and Wudil, A.M. (2013).Partial-purification and Characterization of Angiotensin Converting Enzyme Inhibitory Proteins from the Leaves and Seeds of Moringaoleifera. International Journal of Biochemistry Researchand Review,5(1): 39-48.

Akinterinwa, A., Osemeahon, S.A., Akinsola, A.F. and Reuben, U. (2014).Physicochemical and Pasting Chracterization of Carboxymethylated Scarlet Runner Bean (Phaseoluscoccineus) Starch. Journal of Agriculture and Food Technology, 4(2):13-20.

Aprilita, R., Maksum, R., Abdul, M. and Suyatna.F.D. (2013). Screening Angiotensin Converting Enzyme (ACE) Inhibitor Activity of Antihypertensive Medicinal Plants from Indonesia. International Journal of Pharmacy Teaching and Practices. 4(1): 527-532.

Aremu, M.O.,Olaofe.O. andAkintayo, E.T. (2006). A comparative study on the chemical and amino acid composition of some Nigerian underutilized legume flours. Pakistan Journal of Nutrition, 5: 34-38.

Barbana, C. and Boye, J. (2011). Angiotensin Iconverting enzyme inhibitory properties of lentil protein hydrolysates: Determination of the kinetics of inhibition. Food Chemistry, 127: 94101. inhibitory activity (Choi et al, 2001). Fujita and Yoshikawa (1999) attributed this to the fact that other factors such as route of administration, food matrix and intestinal absorption play a significant role in the activity of the peptide. Also, several ACE inhibitory peptides with weak in vitro activity produce a strong antihypertensive effect in vivo. Therefore, even if the enzymes affected the partially purified inhibitory peptide obtained from Phaceolus coccineus, they may still be effective in reducing blood pressure.

The ACE inhibitory activity of the partially purified peptide was significantly decreased by sodium, calcium, magnesium, and potassium ions, but addition ofEDTA to the inhibitor did not significantly affect its activity when compared to the control. This shows that the partially purified protein may be a good metal chelator. This is consistent with the result obtained by Dorer et al. (1970).

\section{Conclusion}

In conclusion, this study has established that ACE inhibitory proteins can be purified from scarlet runner beans, and thus, may be beneficial as nutraceuticals or drugs for treatment of hypertension.

\section{Author's contributions}

Abdulazeez, A.M. designed the study, wrote the protocols and managed the statistical analysis. Kurfi, B.G. wrote the first draft of the manuscript. Osumeje, G. carried out the laboratory work. All authors read and approved the final manuscript.

\section{Conflict of Interest}

There are no conflicts of interests

Benitez, L.V. (1989). Amino Acid and fatty acid profiles in aquaculture nutrition studies. in S.S. De Silva (ed.) Fish Nutrition Research in Asia. Proceedings of the Third Asian Fish Nutrition Network Meeting. Asian fish. Society Special Publication. Asian Fisheries Society, Manila Philippines. 1989; 23- 35.

Bernstein, K.E., Frank, S.O.,Wendell-Lamar, B.B., Kandarp, H.S., Jorge, F.G., GonzalezVillalobos, R.A., Xiao, Z.S.andSebastien F. (2003).A modern understanding of the traditional and nontraditional biological functions of angiotensin-converting enzyme. Pharmacological Reviews, 65:1-46

Brown, B. and Hall, A.S. (2005).Renin-Angiotensin System Modulation: The Weight of Evidence. American Journal of Hypertension, 18(9): 127133.

Chia-Ling, J., Shih-Li. H. and Kuo-Chiang, H. (2012). Angiotensin I-converting enzyme inhibitory peptides: Inhibition mode, bioavailability, and antihypertensive effects. BioMedicine, 2: 130136.

Choi, H.S., Cho, H.Y., Yang, H.C., Ra, K.S. and Suh, H.J. (2001). Angiotensin I-converting enzyme inhibitor from Grifolafrondosa. Food Research International,34: 177-182.

Cushman, D.W. and Cheung, H.S. (1971). Spectrophotometric assay and properties of angiotensin converting enzyme from rabbit lungs. Biochemical Pharmacology, 20(7): 163748. 
Dorrer, F.E., Skeggs, L.T., Khan, J.R., Lentz, K.E. and Levine, M. (1970). Angiotensin converting enzyme. Analytical Biochemistry.33: 102.

Figen, M.T. (2006). Saponin versus plant fungal pathogens. Journal of Cell and Molecular Biology, 5:13-17.

Freytag, G. andDebouck, D.G.(2002). Taxonomy, distribution and ecology of the genus Phaseolus (Leguminosae-Papilionoideae) in North America, Mexico and Central America. Botanical Institute of Texas, Fort Worth, Texas, United States. 300 pp.

Fujita, H. and Yoshikawa, M. (1999). LKPNM: A prodrug-type ACE-inhibitory peptide derived from fish protein. Immunopharmacology. 44: 123-127.

Gupta, R., Mathur, M., Bajaj, V.K., Katariya, P., Yadav, S. and Kamal, R. (2012). Evaluation of antidiabetic and antioxidant activity of Moringaoleiferain experimental diabetes. Journal of Diabetes. 4(2):164-171.

Kearney, P.M., Whelton, M., Reynolds, K., Muntner, P., Whelton, P.K., He, J.and Whelton, H. (2005).Global burden of hypertension: analysis of worldwide data". Lancet, 365 (9455): 217-223.

Loizzo, M.R., Said, A., Tundis, R., Rashed, K., Statti, G.A., Hufner, A. andMenichini, F. (2007). Inhibition of angiotensin converting enzyme (ACE) by flavonoids isolated from Ailanthuexcels (Roxb) (Simaroubaceae). Phytotherapy Research, 21:32-36.

Mittal, B.V. and Singh, A.K. (2010). Hypertension in the developing world: challenges and opportunities. American Journal of Kidney Disease,55:590-598.

Mizutani, K.K., Othani, J.X.W. and Tanaka, O. (1984).Saponins from Anemone rivularis. PlantaMedica, 51:327-331.

Ojeda, D., Jiménez-Ferrer, E., Zamilpa, A., HerreraArellano, A., Tortoriello, J. and Alvarez, L. (2010). Inhibition of angiotensin converting enzyme (ACE) activity by the anthocyanins 10 delphinidin- and cyanidin-3-Osambubiosides from Hibiscus sabdariffa. Journal of Ethnopharmacology, 127(1):7-10.
Ottaviani, J.I., Actis-Goretta, L., Villordo, J.J. andFraga, C.G. (2006). Procyanidin structure defines the extent and specificity of angiotensin I converting enzyme inhibition. Biochimie, 88:359-365.

Persson, I.A.L, Persson, K. andAndersson, G.G. (2009). Effect of Vaccinummyrtillusand its polyphenols on angiotensin-converting enzyme activity in human endothelial cells. Journal of Agricultural and Food Chemistry,57:4626-4629.

Schmieder, R.E., Hilgers, K.F., Schlaich, M.P. and Schmidt, B.M. (2007). Renin-angiotensin system and cardiovascular risk. Lancet,369:1208-1219.

Suttie, J.M.(1969). The butter bean (Phaseoluscoccineus L.) in Kenya. East African Agricultural and Forestry Journal, 35: 211-212.

Viernes, L.B.G., Garcia, R.N., Torio, M.A.O. and Angelia, M.R.N. (2012). Antihypertensive peptide from vicilin, the major storage protein of mung bean. Journal of Biological Sciences, 12:393-399.

Westphal, E. (1974). Pulses in Ethiopia, their taxonomy and agricultural significance. Agricultural Research Reports 815. Centre for Agricultural Publishing and Documentation,Wageningen, Netherlands. $276 \mathrm{pp}$.

Sebastien F. (2003).A modern understanding of the traditional and nontraditional biological functions of angiotensin-converting enzyme.Pharmacological Reviews, 65:1-46 